\title{
Introduction: migration and social policy: key trends and debates
}

Gary P. Freeman and Nikola Mirilovic

This volume seeks to accomplish four goals. First, it hopes to bring to the community of migration and social policy researchers up-to-date and authoritative summaries and reviews of the state of play in the field. Second, we wished to draw on the significant contributions that arise out of several social science disciplines. Toward that end, we solicited chapters written by persons who hang their hats in different departments but who are able to reach across disciplinary boundaries theoretically and methodologically. In this we have succeeded beyond our expectations. Political scientists, economists, sociologists and historians have all contributed chapters.

Third, contributors were charged with the task of exploring important issues arising from migration and social policy from the standpoint of a theoretical framework that allowed them to pose hypotheses that could be tested with data. Readers with strong interests in the normative and ethical dimensions of our topic will find, we trust, evidence posed against data that should in the best of circumstances illuminate if not settle serious normative disagreements. Fourth, we deliberately invited colleagues divided by age and prominence. This handbook includes chapters penned by some of the most distinguished scholars writing on the topic; others were written or co-authored by promising junior scholars.

A word may be in order on our understanding of the meaning of migration and social policy. We take a broad view of the manner in which migration may interact with social policy. The most direct means relates to the programs developed by receiving states to support immigrants and to encourage their integration. Beyond that, however, we are interested in the participation of immigrants in the benefits of public programs created in the first instance for citizens, when there is reason to expect that immigration affects the employment and income of natives, if the presence of immigrants has the effect of altering the political dynamics of welfare policies, if the welfare state might serve as a factor in the choice of destination countries by potential immigrants, if emigration has implications for social policy in the country of origin, if the relationship between immigration and security is perceived to involve threats to the country of residence and this impacts immigration policies, or if migrants become the focus of nativist opposition.

We subdivide our chapters into seven categories that do only a little violence to their actual content. Rather than attempt to summarize what are quite complex contributions, we identify the most significant analytical themes addressed by our contributors.

Several chapters present thoughtful arguments for either new or rethought analytical perspectives in migration research. Boswell's intriguing suggestion of an epistemic turn in immigration policy is the most general in scope. She is interested in when and how policymakers use expert knowledge. She also explores changes in the funding of 


\section{Handbook on migration and social policy}

research and the political implications of the trend toward government funding and the consequent official production of expertise. Helbling produces an encyclopedic and convincing critique of existing indices that try to capture some or all the dimensions of immigration, integration and citizenship. The creation of indices, as Helbling amply documents, is a growth industry and a welcome development. Taxonomy is a necessary step toward a more rigorous approach to migration research. Janoski builds on previous empirical work to make the case for innovative approaches to social-process and political-economy explanations for comparative diversity in naturalization outcomes. $\mathrm{He}$ addresses the often overlooked problematic status of birthright citizenship in the calculation of naturalization rates. Peters and Vink also emphasize the importance of addressing the relationship between immigration and citizenship rules (see also Mirilovic, 2014). Lucassen melds a rich account of the historical migration experience of Eurasia to both broaden our understanding of what sorts of internal and external population movements should count as migration and to develop an empirical indicator with which to measure the extent and import of migration in the region since 1500.

Four chapters delve into the question of how far the close study of migration's relationship to trade, foreign direct investment and the variety and mobility of a country's factor endowments can shed light on a specific social policy such as public education and perennial economic dilemmas of whether emigration or immigration makes a net contribution to economic development. Margaret Peters argues that, whereas mass migration in the nineteenth century was characterized by open migration and restricted trade, in the contemporary era we see just the opposite. She accounts for this with the novel claim that the business sector in the twenty-first century enjoys alternatives to importing cheap, unskilled foreign labor: to wit, by moving production abroad. This option is cheaper in both economic and political terms and is much more feasible today than in the past due to technological advances in transport, travel and long-distance communication.

Business has been the most reliable and resource-rich segment of coalitions supporting open immigration, Peters notes, but as a result of the changes globalization has wrought it no longer has strong incentives to spend time and money pressing for policies to admit low-skilled migrants. Governments are, consequently, free to restrict such migration. This explains, Peters argues, the tendency across all rich capitalist countries to restrict unskilled labor in defiance of the predictions of the Stolper-Samuelson factor model of international trade. Mariana Medina brings a background in political economy to bear on the puzzle of why the USA fails to recruit more skilled immigrants when there is little opposition and a consensus that it would benefit the economy. Her explanation focuses on the decision to bundle into a comprehensive legislative proposal a points system designed to select for skills with larger and more contentious issues. Neither Canada nor the UK adopted such a procedure in their successful legislative initiatives.

A major theme in a number of the chapters is the importance of institutions. Greenhill and Lahav and Perliger argue that the institutional setting shapes the relationship between immigration and security. Crepaz also observes that the institutional context affects how destination-country citizens view the relationship between immigration and the welfare state. According to Leblang, institutions affect the availability of information, which in turn helps shape diaspora investment patterns. Ruhs argues that varieties-of-capitalism institutional differences as well as domestic liberal institutions affect immigration 
policymaking. Immigration outcomes are shaped by the institutional settings across a number of policy areas.

Ortega and Tanaka make two key claims about the impact of immigration on public education. First, they claim that the presence of immigrant children in public schools leads to native flight to private schools. Second, they argue that immigration reduces political support for public education among voters. This is an important if tentative finding as it moves the debate about the possible effects of diversity on national welfare states to the subnational level, at least in those countries with decentralized educational systems.

Facchini, Mayda and Murard examine the determinants of public opinion toward redistributive government policies in Europe. They distinguish between areas where immigrants are predominantly unskilled relative to natives and areas where immigrants are highly skilled relative to natives. They find that in the former case relatively skilled natives tend to oppose redistributive programs. The underlying logic of the argument is based on the net fiscal impact of immigration, which the authors contend is likely to be negative for unskilled migrants. The authors also find that the immigrants themselves tend to favor redistributive government policies.

Soroka, Harrell and Iyengar hypothesize that the impact of immigration on social spending will differ across sub-domains of social policy. Different entitlement programs have different rules that determine who can benefit from them. Destination-country citizens perceive some programs, but not others, as disproportionately benefiting immigrants. Examining survey data from Canada, the UK and the USA, they find that antiimmigrant sentiment reduces support for public spending on students and the poor (and in the UK on the unemployed as well). In contrast, there is a positive relationship or no relationship between anti-immigrant sentiment and support for spending on women and on the elderly. Diane Sainsbury produces a comprehensive overview of the differences in the experiences of women and men as they encounter both general social programs as well as more specific measures for migrants. She reminds us that there is variation across sub-groups as well as across sub-policies.

Crepaz criticizes the claim that immigration and the diversity it creates are a major threat to the sustainability of the welfare state. He summarizes the findings of previous studies of how ethnic diversity affects attitudes toward the welfare state and concludes that the results are mixed. But he offers a host of factors that might mediate this relationship making any substantial decline in support unlikely. He also argues for distinguishing between different types of trust, which, he claims, have different implications for the relationship between immigration and the welfare state. This is highly relevant to the matter of the impact of immigration policymaking and its relationship to the welfare state. Crepaz also argues for putting more emphasis on the institutional setting, including on variation in the extent to which policymakers are responsive to voters' demands. One example is the argument that authoritarian states adopt more permissive immigrant admissions policies than democracies (e.g. Breunig et al., 2011; Mirilovic, 2010). Democracies may also be more likely targets for coercively engineered migrations, as Greenhill argues in her chapter in this volume. Examining institutional variation further could answer questions about why the relationship between immigration and the welfare state may differ cross-nationally.

Wright notes that policymakers in the UK and in Australia view immigration and 


\section{Handbook on migration and social policy}

social policy as linked. He claims that policymakers tighten social policies involving migrants (immigrants' access to unemployment benefits, for example) to send a signal that will reassure voters concerned about the negative impact of immigration. The perceived effects of immigration on the welfare state are, Wright argues, partly a function of how that impact is portrayed to voters by policymakers.

The authors of several chapters address the question of whether destination-country citizens will be less likely to support social welfare spending when they perceive such spending as disproportionately benefiting immigrants. Answers to that question may depend on variation across types of immigrants (e.g. skilled versus unskilled), institutional rules that govern different sub-domains of social policy (and determine which groups and individuals will tend to benefit from them), and in the institutional setting, such as regime-type variation. This illustrates the importance of testing across a large number of different contexts, as is carried out, for example, by Facchini, Mayda and Murard. Shpaizman argues that the differences between skilled and unskilled immigration are important in terms of immigrant integration in Israel. An issue that merits further study is the views of the immigrants themselves about immigration and its relationship with the welfare state. Ortega and Tanaka point out that the preferences of immigrants as voters matter in shaping public policy, especially in the long run.

Does the national-level government play the key role in governing immigration outcomes? Immigration may be regulated at the lower (local or state) level or the higher (regional or global) level. These questions are particularly relevant to the study of immigrant integration, which is to an increasing extent a responsibility of subnational level authorities (see Ireland and Joppke and Eule in this volume and Freeman and Tendler, 2012).

According to Money, Lockhart and Western, global efforts to regulate immigration are not likely to be successful. Migrants' rights advocates seek to strengthen international norms that constrain states and protect migrants. However, receiving states prefer not to be constrained and seek to preserve their sovereignty. The authors contend that, because receiving states are unlikely to approve or to conform to international agreements, such agreements are largely toothless.

Geddes and Hadj Abdou examine regional integration within Europe. The European Union has made increasing efforts to regulate immigrant admissions and asylum policies, making it an exception to the general pattern whereby institutionalized international cooperation on immigration is rare. Moreover, the process of absorbing immigration and refugee issues by the Community has been impressive. Nevertheless, in their understated and even-handed exposition, Geddes and Hadj Abdou argue that member-state reluctance to embrace free movement either for third-country nationals or EU citizens from recent accession states could point to limits to the Union's integrative aims. The authors claim that almost anything member states might do to avoid an influx of unwanted migrants from the Community would be in violation of weighty treaty obligations that can neither be easily breached nor renegotiated without bringing into question the entire European project.

Joppke and Eule emphasize two trends in contemporary immigration policymaking in Europe. First, they argue that there is a growing emphasis on immigrant integration and on the idea that governments should actively promote that integration. This 
process partly reflects criticism of multiculturalism in the Netherlands and elsewhere. Second, subnational authorities (i.e. the local authorities) play an important role in civic integration implementation across European countries. Joppke and Eule challenge the idea of the primacy of the national level in two ways: by emphasizing cross-national trends within Europe and by emphasizing the relevance of local-level governance.

Crepaz makes the case for the importance of the relationship between immigration and social welfare on the subnational level. He notes that subnational locales where immigrants can vote tend to experience an expansion in social welfare programs. Further study of the extent to which these developments reflect the voting choices of immigrants or the impact of immigration on the preferences of the native born would shed additional light on debates regarding the impact of immigration on the welfare state.

Ireland also makes the case for studying local-level immigration policymaking. He sees two advantages of such research. First, local-level policymaking is increasingly substantively important and city-level authorities play a major role in immigrant integration. Second, studying the local level can facilitate constructing methodologically sound research designs - something in short supply, in his opinion.

The implications of immigration for the security of destination countries is a highly fraught issue. A relatively new area of study before 9/11 and subsequent events, the question has attracted more attention (Adamson, 2006; Meyers, 2004; Rudolph, 2003). Messina addresses the relationship between immigration and the rhetorical terms in which it is discussed. Analyzing the concept of securitization, Messina argues that perceptions of threat that are central to the idea of securitization are socially constructed and not necessarily connected to a firm empirical footing. He cites opinion-poll evidence to support his conclusion that perceptions of immigrants as a threat are not driven by the 9/11 terrorist attack.

A potential problem for the securitization argument is that it frequently asserts that a threat is exaggerated without specifying what the objective, unexaggerated level of threat would be. Moreover, arguments that assert that elites manipulate the public in pursuit of their political self-interest can be criticized for not treating actors consistently. According to these arguments, elites are rational and self-interested, while the members of the public are manipulated so as to ignore their own self-interest. Future research should explore the question of how and why the determinants of threat perceptions vary across members of the public. Messina argues that the absence of an effect of the attack on 9/11 on public views of immigrant threat may indicate the limitations in the extent to which securitization affects the views of the public.

Lahav and Perliger take up the challenge and examine data (from the UK, France, Germany and the Netherlands) about the participation of immigrants in protest activity as well as in politically motivated acts of violence (including acts of terrorism and extensions of external conflicts) within the destination country. Among other things, they argue that such activity may be more frequent in countries that adopt multicultural integration policies (i.e. the UK) than in other institutional settings. They point out the confounding variables that future research should address, including variation in foreignpolicy choices that destination countries adopt that may have implications for the type of protest activity that occurs within those countries. Future research should incorporate testing across a larger number of destination countries and of diaspora groups to assess 


\section{Handbook on migration and social policy}

the relationship between immigration, institutional settings and security. Furthermore, it is important to distinguish between peaceful protests (which are an important component of democracy) and violent attacks.

Most of the chapters in this volume deal with destination countries, as does most of the migration literature. What are the implications of emigration for those who stay in the sending country and for social welfare policies there? Social scientists have debated these questions over several decades. Concerns over the negative consequences of emigration are captured by the concept of a "brain drain." The idea that emigration should be restricted or discouraged has, however, lost popularity over time. Other scholars emphasize benefits of emigration for sending countries, such as remittances (for debates on the economic impact of "brain drain," see Beine et al., 2001).

Leblang argues in this volume that the presence of a diaspora increases investment, both FDI and portfolio, from the host to the home country. He argues that the causal mechanism is the availability of information. Diasporans have a familiarity with the conditions in their country of origin that makes it easier to invest there. Given the competition that many developing countries engage in to attract foreign capital, the implication of increased investment for sending countries is probably a positive one. Increased foreign investment could lead to the availability of more resources for social welfare spending.

Rajan's chapter focuses on the impact of emigration on India in general and on the Indian state of Kerala in particular. Like Leblang, Rajan emphasizes positive economic consequences of emigration. India benefits from remittances that Indians based abroad, notably migrant workers based in Gulf Cooperation Council countries, send to India. Rajan also points out, however, that emigration generates social costs. Migration of workers to the GCC generates material benefits for the spouses and the children of migrant workers, but also involves social costs when family members are separated from one another for extended periods.

The role of diasporas and emigrants in transnational politics and in international economic networks is a growing area of study. Leblang emphasizes the relevance of institutional settings; the literature could say more about how variation in institutional settings affects immigration. Variation across different types of immigration also has implications for social policy. The social costs of emigration may be higher for temporary migration that is more likely to involve extended separation between family members than for permanent migration.

\section{REFERENCES}

Adamson, Fiona B. 2006. "Crossing borders: international migration and national security." International Security, 31(1): 165-99.

Beine, Michel, Frederic Docquier and Hillel Rapoport. 2001. "Brain drain and economic growth: theory and evidence.” Journal of Development Economics, 64: 275-89.

Breunig, Christian, Xun Cao and Adam Luedtke. 2011. "Global migration and political regime type: a democratic disadvantage.” British Journal of Political Science, 42(4): 825-54.

Freeman, Gary and Stuart Tendler. 2012. "United States of America.” In Christian Joppke and F. Leslie Seidle (eds), Immigrant Integration in Federal Countries, Montreal: McGill-Queen's University Press.

Meyers, Eytan. 2004. International Immigration Policy: A Theoretical and Comparative Analysis, New York: Palgrave Macmillan. 
Mirilovic, Nikola. 2010. "The politics of immigration: dictatorship, development, and defense." Comparative Politics, 42: 273-92.

Mirilovic, Nikola. 2014. "Regime type, international migration, and the politics of dual citizenship toleration." International Political Science Review, published online before print, May 29, 2014.

Rudolph, Christopher. 2003. "Security and the political economy of international migration." American Political Science Review, 97(4): 603-20. 
Gary P. Freeman and Nikola Mirilovic - 9781783476299 